Images in...

\title{
Lifting the veil: a case of lobar atelectasis
}

\author{
U Salati, A Smyth, C A Wall \\ Department of Nephrology, Adelaide \& Meath Hospital, Tallaght, Dublin, Ireland
}

Correspondence to A Smyth, andrewsmyth@physicians.ie

\section{DESCRIPTION}

A 16-year-old, non-smoking, girl presented with a 1-week history of productive cough. She was diaphoretic, had no evidence of rigors, temperature was $37.4^{\circ} \mathrm{C}$, respiratory rate was $18 / \mathrm{min}$, oxygen saturation on room air was $94 \%$ and blood pressure was $110 / 50 \mathrm{~mm} \mathrm{Hg}$. Auscultation of her chest was normal. Investigations showed a $\mathrm{C}$ reactive protein of $116.9 \mathrm{mg} /$ litre and arterial blood gas on room air $\mathrm{PaO}_{2}$ of $10.2 \mathrm{kPa}$. Initial chest x-ray (CXR) showed diffuse haziness of the left hemithorax with air bronchograms adjacent to the left hilum and upward displacement of the left hilum and diaphragm (figure 1). A diagnosis of pneumonia with left upper lobe collapse was made. She was started on antibiotics and had chest physiotherapy. CT of the thorax was considered but not performed due to clinical improvement and her young age. Follow-up CXR 3 days later showed re-expansion of the left upper lobe with improvement in lung volume; a dense left upper lobe consolidation with prominent air bronchograms (figure 2). Left upper lobe collapse can present with a 'veil-like' opacity of the left lung field with elevation of the left hilum and hemidiaphragm. ${ }^{1}$ This is because the left upper lobe collapses anteriorly. There may also be an area of crescentric lucency between the mediastinum and the atelectatic upper lobe. This is known as the Luftsichel sign. ${ }^{2} 3$ This represents the upward expansion of one of the segments of lingular lobe. Other potential aetiologies of such findings on CXR include cystic fibrosis and asthma, but our patient had no evidence or history of either.

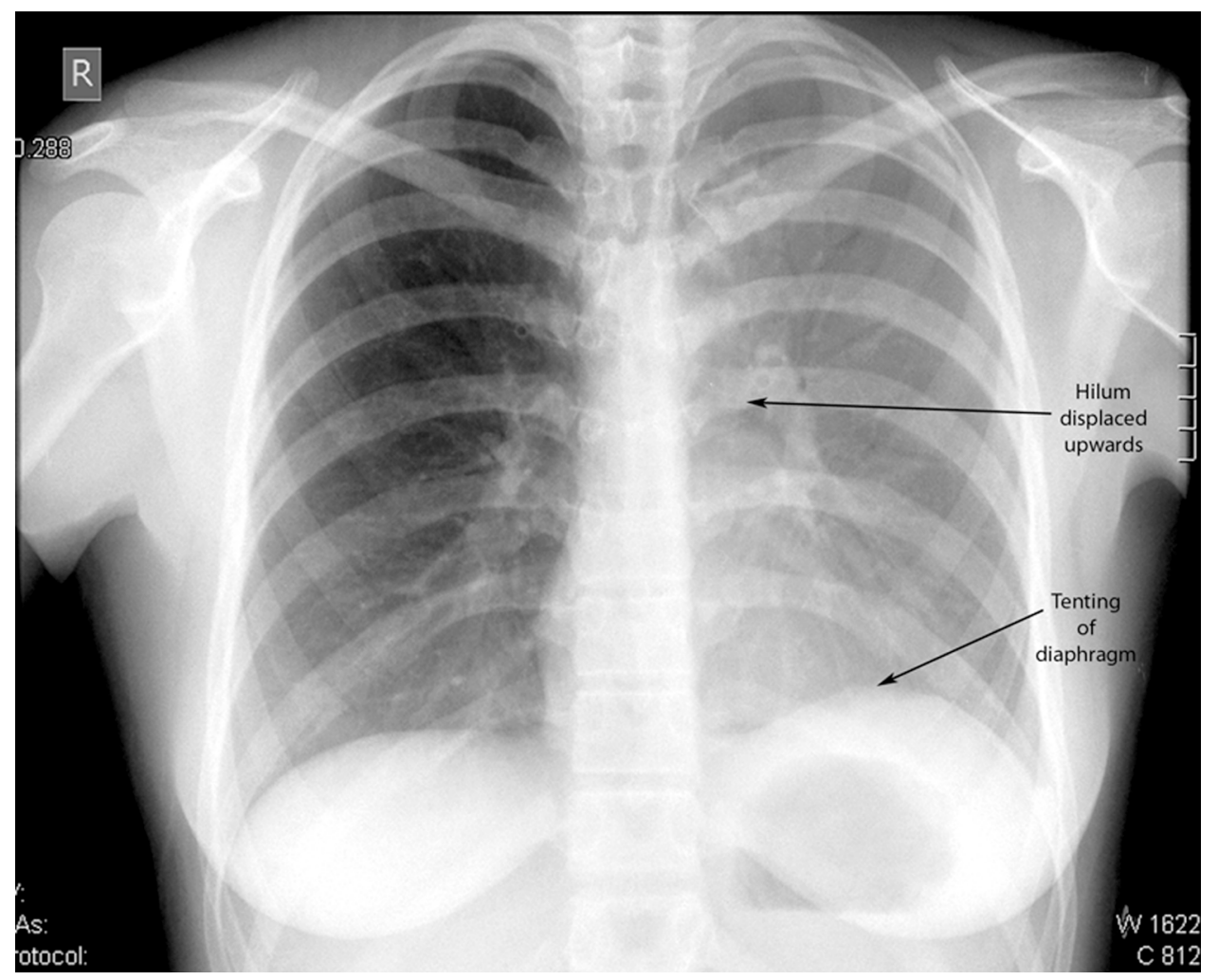

Figure 1 Initial CXR showing the veil-like opacification of the left hemithorax with upward displacement of the left hilum and minor tenting of the left hemidiaphragm. 


\section{BMJ Case Reports}

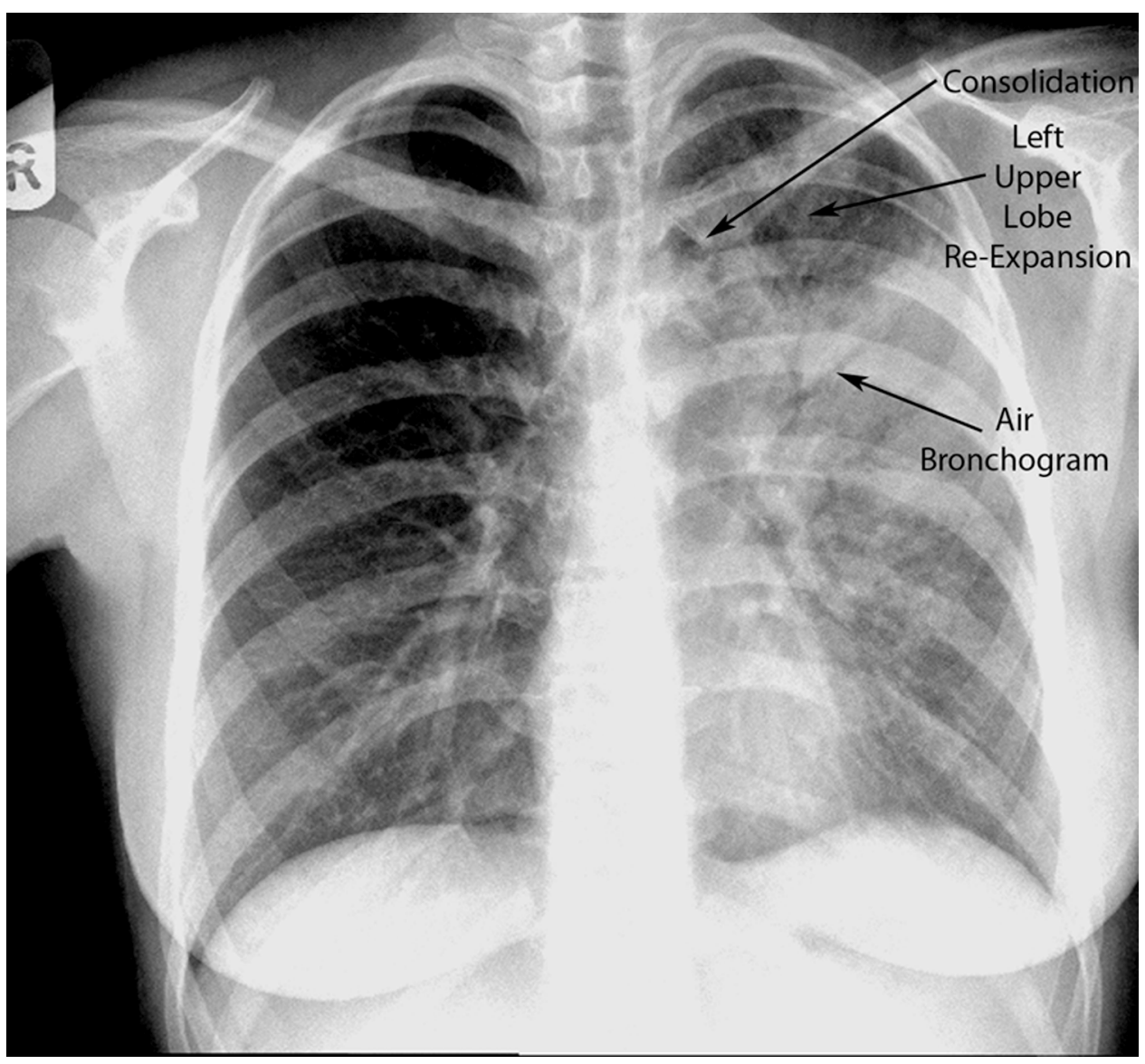

Figure 2 Follow-up CXR demonstrating some re-expansion of the left upper lobe. Prominent air bronchograms are noted.

Competing interests None.

Patient consent Obtained.

\section{REFERENCES}

1. Proto AV. Lobar collapse: basic concepts. Eur J Radiol 1996;23:9-22.

2. Webber M, Davies P. The Luftsichel: an old sign in upper lobe collapse. Clin

Radiol 1981:32:271-5.
3. Ashizawa K, Hayashi K, Aso N, et al. Lobar atelectasis: diagnostic pitfalls on chest radiography. Br J Radiol 2001;74:89-97.

\footnotetext{
This pdf has been created automatically from the final edited text and images.

Copyright 2010 BMJ Publishing Group. All rights reserved. For permission to reuse any of this content visit http://group.bmj.com/group/rights-licensing/permissions.

BMJ Case Report Fellows may re-use this article for personal use and teaching without any further permission.

Please cite this article as follows (you will need to access the article online to obtain the date of publication)

Salati U, Smyth A, Wall CA. Lifting the veil: a case of lobar atelectasis. BMJ Case Reports 2010;10.1136/bcr.01.2010.2691, date of publication

Become a Fellow of BMJ Case Reports today and you can:

Submit as many cases as you like

- Enjoy fast sympathetic peer review and rapid publication of accepted articles

- Access all the published articles

- Re-use any of the published material for personal use and teaching without further permission

For information on Institutional Fellowships contact consortiasales@bmjgroup.com

Visit casereports.bmj.com for more articles like this and to become a Fellow
} 